The Geneva Papers on Risk and Insurance, 20 (No. 74, January 1995) 3-6

\title{
The Dynamics of the Scandinavian Insurance Market: Some Observations
}

\author{
by Björn Wolrath*
}

Traditionally insurance companies have acted as important but almost invisible players in Scandinavian financial markets. Analysis and discussion of their investment portfolios have been essentially limited to equity and solvency analysts. Yet the logic behind their investment decisions is ultimately of great importance to a number of stakeholders: supervisory authorities, clients, employees. It has been implicit that prudence is desirable. But the concept of prudence actually extends beyond today's known yield requirements to tomorrow's unknown scenario. As investors major institutions must have the right to exercise in society the same kind of corporate governance that applies in the private sector. The decision by Skandia Insurance Company Ltd in July 1994 to cease buying Swedish government bonds and to divest its own relatively small current holdings caused a considerable comment and a significant reaction in the financial markets.

Our motivation was simple. Insurance companies in particular have long-term responsibilities, to their policyholders and to the shareholders. Solvency presupposes prudent underwriting and advanced investment practices. As major investors in the infrastructures of a society, insurance companies have a duty to encourage sound fiscal development rather than financing an ever growing national debt.

The majority of those contacting us, both shareholders and clients, have been favourable to our stand. The negative reactions have come from the ranks of the politicians, which was predictable. Our action has been characterized by some as an undue participation in the political debate, an attitude I feel demonstrates a lack of awareness of the workings of today's economies and of the essential interface between the corporate world and the political sphere.

The social and economic responsibility of major private institutions in a nation is not less because they are not part of the state apparatus. On the contrary, since they have traditionally been exposed to the requirements of surviving in situations of free competition, and their performance and prospects are judged in part on conditions in their domicile, corporations are actually particularly well suited to comment on the manner in which politicians conduct the state finances. It is axiomatic that the stability of all companies, be they insurers, bankers or manufacturers, stands in some sort of relation to the market in which they sell their products and make their investments.

\footnotetext{
* President and Chief Executive Officer, Skandia Insurance Company Ltd., Stockholm.
} 
The case of Sweden is not unique but it is illustrative. Calculations from OECD indicate that the national debt will be on the level of 123.4 percent of the GNP by 2000 . The situation is already alarming today: the general government deficit is anticipated to be 11.5 percent of GDP in 1994 and the stock of public debt, now at 93 percent GDP, is growing rapidly. Since the government is currently spending 67 percent of GDP it is obvious that a major curtailment is imperative.

Swedish insurance companies accounted for 20 percent of the state's total loan requirements in 1993. Against that background we at Skandia questioned the advisability of lending large sums to the state, which used the funds for consumption, that is interest payments and transfers within the social insurance system.

Our action was intended to create the prerequisites for measures to reduce the nation's need to borrow. That trend would in turn lead to falling interest rates and hence to more activity in the stagnating parts of the Swedish economy. This would also increase the value of investors' bond, share and real estate portfolio.

That vision includes more employment opportunities and increased investment activities. The question has other aspects as well, since an insurance company obviously stands to gain from a situation where investments in industry create greater interests to be insured and a population with the necessary disposable income to invest in pension and savings products. Indeed, premium growth in the non-life markets in Scandinavia in the last year or so has been hampered not only by competition but also by the limited investments by businesses and individuals requiring insurance, which can be ascribed to the recession. This has been true in particular for commercial and industrial lines.

We have been asked to indicate when we would begin buying government bonds again. The answer is of course that to do so Skandia must consider a purchase of bonds to be in the best interests of its shareholders and policyholders, taking into account all the elements discussed above. It is a complex question. It is also fundamentally a political question, and a question of defining the responsibility a large institution has in generating and administering wealth.

Since Sweden has been regarded as an uncertain borrower the state has been obliged to raise bond rates in order to attract lenders. It has thus become more expensive for Swedish companies to borrow for investments and increased activities. Unemployment has continued at a high level.

The major issue is confidence in the economy. There is however rapid growth in export industry and a relatively healthy demand domestically which should provide politicians with an opportunity to deal with the deficit. A recent forecast done by Svenska Handelsbanken indicated that probable measures undertaken by any new government after the election to take advantage of the recovery of the international economy could strengthen the state budget by saving some SEK 40 billion in 1994-95 over and above the savings announced. This additional savings is what the bank feels is required to restore confidence. The political programs of all the parties did include savings obtained by such moves as reduced indexation of pensions, student contributions and other transfers of funds within the welfare system, but to an insufficient extent. Any government policy would have to address the issue of inflation as well. For non-life insurance companies any rise in inflation rates is a threat.

The results of the Swedish elections in September 1994 have not really resolved the question of mandate for change, since the Social Democrats have initially chosen to work 
as a minority government, a stance which makes them inevitably dependent on other parties with diverging views on such essential issues as EU membership and tax programs. The positive Swedish vote in the EU referendum in November 1994 was achieved in spite of a split in the Social Democratic party, a split which is likely to make a consensus on public spending difficult, since its origins lie in diverging perceptions of the role of government.

Undoubtedly, the politicians' response is belated, a fact that has set in motion a series of events. Uncertainty about the Swedish economy has grown over the last year and has meant that foreign investors began to sell their holdings of Swedish government bonds during the winter and spring. This was a significant percentage since in 1993 foreign investors had accounted for almost half of the net purchases. The trend has continued into the autumn, with major Swiss, UK and US fund managers demonstrating their lack of confidence in the Swedish economy by selling all their Swedish bonds.

Turmoil in the financial markets naturally has an impact on the insurance sector. The Swedish and Norwegian insurance industries had made a good recovery in 1993 from the traumas of 1992 but the developments in the bond market in 1994 entailed considerable setbacks in the results of investment activities. Even share prices have reflected the interest rate levels. Responsible investment practice requires a long-term approach taking many factors into account.

In Scandinavian society significant and positive structural changes are in progress, which will open new sectors for the industry. Scandinavian insurance markets are in a dramatic phase of evolution as the governments are increasingly obliged to rethink priorities. It is an exaggeration but not entirely inaccurate to compare this process with what is happening in the planned economies now in a phase of transformation. The change entails a shift of responsibility from the welfare state to the individual who must then make choices that have not been previously available. How much pension is enough? How can I gauge the levels of risk in various pension options? How much health insurance is enough? Should I wait for my operation at public facilities or get insurance for prompt service at a private hospital ? In brief, the concept of insurability is being redefined and expanded.

As this shift of responsibility to the private sector continues it will place demands on the stability, solvency and liquidity of the private insurance sector. This new situation will also require a sophisticated supervisory service acquainted with the qualities of new products and with the conditions in which insurance companies operate in other nations. Solvency will of course be a major consideration but there are other areas to be addressed as well. Equitable competition is one of them. The Norwegian requirement for a guaranteed yield on unit-linked policies effectively stopped domestic companies from offering the product at the same time as currency deregulation permitted Norwegians to purchase foreign policies. The rules are due to be changed at some point by the end of 1994 or early 1995 , but the domestic insurance industry has undeniably lost time. The activities of those domestic companies not already having available inhouse unit-linked expertise are testimony to this fact.

In the Scandinavian countries as in the rest of Europe, demographic changes have made the savings and pension sector the greatest growth area. In Sweden, surveys have shown that 75 percent of the public wants a private pension policy to supplement government pensions. At the same time the mix of the market has changed. In 1993, some 60 percent of new premiums were attributable to unit-linked policies while in 1992 the share was 
only 40 percent. These changes in savings habits indicate more sophisticated customers, demanding investment vehicles promising higher returns. It is also likely that this growing market will be less tax driven than previously, reflecting a genuine demand and need for security.

The Swedish pension reform is expected to open a new MSEK 14,000 market in the first year, as citizens will have to build up their own premium reserves, electing an institution to invest for them. This is a significant addition to a market that included MSEK 23,800 in new sales in 1993. Privatization of state and municipal companies and institutions will also create greater pension needs in the private sector. The Norwegian life and savings market amounted to MSEK 20,000 and the Danish to MSEK 22,000 during the same period. Significant expansion can be expected in the life assurance sector in both these nations, particularly in Norway, as legislation changes in accordance with EU Directives. This harmonization process will still have to be implemented in spite of Norway's no-vote to the EU, since the nation remains a member of the EEA. One way or the other, Scandinavia stands on the threshold of some of the most significant changes in the fabric of society to take place in this century. This transfer of social responsibility from the state to the private sector entails exciting opportunities for the insurance industry at the same time as it puts new demands on the long-term stability of the sector. Hence it is probable that in the future financial institutions providing such essential services as pensions will be increasingly called on to participate in the national debate, since they will play an ever larger role in the life and fortunes of the citizenry. 